\title{
Spigelian Hernia in 2-Year-Old Male Child: A Rare Case Report
}

\author{
Kamal N Ratan ${ }^{1}$ and Shubhangi Sharma ${ }^{2 *}$ \\ ${ }^{1}$ Department of pediatric surgery, Pandit Bhagwat Dayal Sharma Post Graduate Institute of Medical Sciences, India \\ ${ }^{2}$ Department of radiodiagnosis, Pandit Bhagwat Dayal Sharma Post Graduate Institute of Medical Sciences, India
}

Submission: March 23, 2017; Published: June 07,2017

*Corresponding author: Shubhangi Sharma, Department of radiodiagnosis, Pandit Bhagwat Dayal Sharma Post Graduate Institute of Medical Sciences, India, Email: sbhubhangi3191@gmail.com

\begin{abstract}
A Spigelian hernia is a rare condition and accounts for only $1.5 \%$ of the abdominal hernias and is even rarer in children. The diagnosis requires a high level of clinical suspicion along with the aid of radiological investigations, as they are intraparietal hernias. A 2-year-old male child presented with Spigelian hernia with bilateral cryptorchidism. Radiological investigations were done to confirm the diagnosis of a Spigelian hernia and to know the detailed anatomy. The Spigelian hernia was repaired and bilateral orchidopexy was done after 1 month period

Keywords: Spigelian hernia; Ultrasound; Orchidopexy
\end{abstract}

\section{Introduction}

A Spigelian hernia is a rare condition and accounts for only $1.5 \%$ of the abdominal hernias [1]. It is even rarer in children. The diagnosis requires a high level of clinical suspicion along with the aid of radiological investigations, as they are intraparietal hernias. A Spigelian hernia is a ventral hernia which occurs along the linea semilunaris, which runs alongside the lateral border of anterior rectus sheath, due to the weakness of fibers of internal oblique and transeversus abdominis muscles. The maximum incidence of a Spigelian hernia is distal to the umbilicus.

\section{Case Report}

We report a case of a 2-year-old male child presented to us with complaints of on an off swelling in right side of abdominal wall associated with dull aching pain. On examination, the swelling was more prominent on coughing and crying. The patient also had patchy hair loss in frontal area, cryptorchidism, deviation of the left eye and tongue tie. Ultrasonography of the swelling revealed a defect in anterior abdominal wall lateral to the rectus muscle with herniation of preperitoneal fat through it. Ultrasonography of scrotal sacshowed theabsence of both testes in scrotal sac as well as in the superficial inguinal region. We did CT scan to confirm the diagnosis of a Spigelian hernia and to know the detailed anatomy. On CT scan herniation of fat was accompanied with herniation of small gut also and testes were visualized in the inguinal canal region (Figure 1).

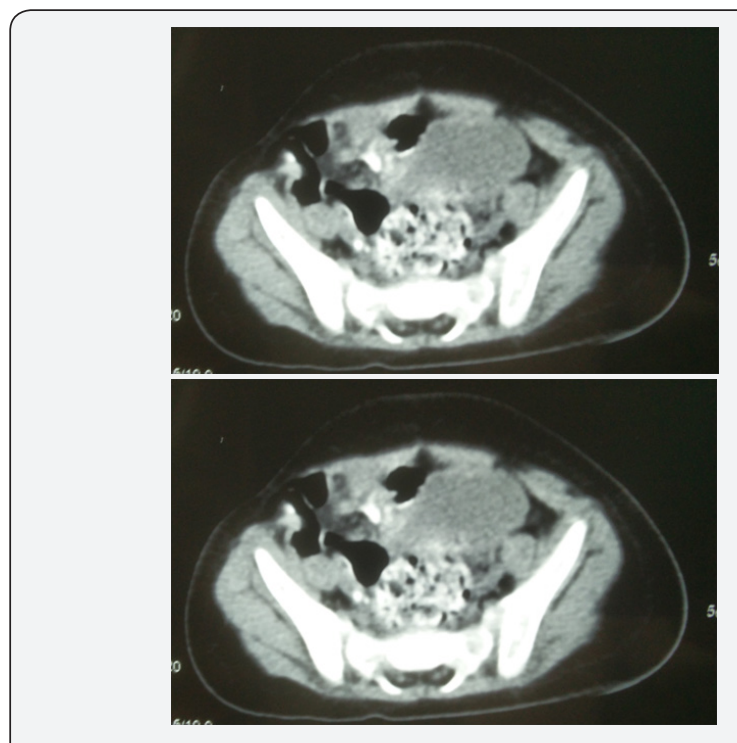

Figure 1: CT images showing herniation of bowel loops and preperitoneal fat through the defect lateral to lineasemilunaris.

The patient was operated with a right transverse incision given at the umbilical level. After the division of skin and subcutaneous tissue, the hernial sac was identified protruding out from a defect lateral to the right border of the rectus abdominis. Contents were identified as preperitoneal fat; the 
preperitoneal fat was excised, Mayo's repair technique was used tofix the defect. The wound was closed, and stitches were removed after 7 days. Bilateral orchidopexy was done after 1 month period. The patient recovered uneventfully (Figure 2).

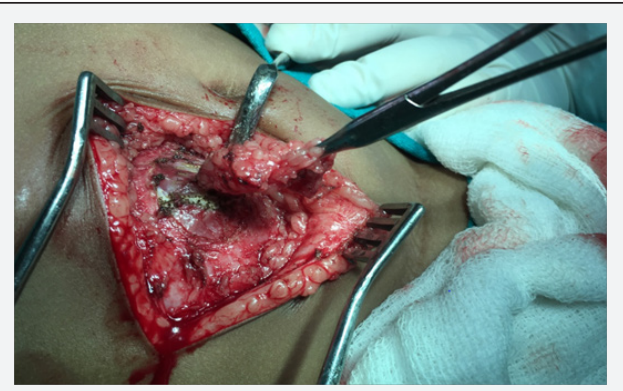

Figure 2: operative image showing herniated omentum and gut.

\section{Discussion}

The primary case of a Spigelian hernia was said in 1933 [1] Only 37 cases have been suggested in the pediatric age group in a review of the literature from 1935 to 2000 [2] In children, the Spigelian hernia is more common in males [3] and is commonly associated with cryptorchidism, in which the undescended testes mostly lie in the hernia sac [4]. However, in our case lied in the abdominal cavity and not in the hernial sac. However, in adults, the Spigelian hernia is more common in females. A Spigelian hernia is a herniation through the Spigelian aponeurosis, which is bounded laterally by the transversus abdominis muscle and semilunar line and the lateral border of the rectus muscle lies medial to it. Most hernias occur at the level of the free lower margin of the posterior rectus sheath.

A hernia normally penetrates the transversus abdominis muscle and internal oblique muscles and enlarges in the area between the internal and external oblique muscles. Space is largest laterally, so large Spigelian hernias go laterally to the Spigelian aponeurosis. The orifice of the hernia sac is usually small and has fibrous edges. This explains the high risk of strangulation in a Spigelian hernia [5]. Most of these hernias occur on the right side. The symptoms of a hernia depend on the contents of the hernia sac. As the neck of the sac is often narrow, the contents can easily undergo strangulation. Pain is the most common presenting complaint.

Ultrasound is often the first investigation of choice for a patient presenting with lump and pain in the abdomen. It is also an indispensable diagnostic tool in Spigelian hernias. Ultrasonography was considered to be the gold standard for a Spigelian hernia [6-8] CT scan is crucial for diagnosis as well as it shows the exact location and size of the defect, thus helps in planning for surgery. In conclusion, the Spigelian hernia is a rare entity which poses a great diagnostic dilemma due to non-specific signs and symptoms. Radiological investigations are crucial for diagnosis, and the hernia is associated with a significant risk of strangulation so should be managed promptly by surgery.

\section{References}

1. Wu CM, Liu TH, Lin HJ, Wang GT (2006) Traumatic spigelian hernia. Injury Extra 37(11): 404-406.

2. Al Salem (2000) Congenital spigelian hernia and cryptorchidism: cause or coincidence? Pediatric Surgery International 16(5-6): 433-436.

3. Strambi S, Pucci V, Liserre J, Spinelli G, Palombo C, et al. (2014) Spigelian Hernia in a 14-Year-Old Girl: A Case Report and Review of the Literature. European Journal of Pediatric Surgery Reports. 2(1): 58-62.

4. Parihar, Dhiraj (2013) Congenital Spigelian Hernia and Cryptorchidism: Another Case of New Syndrome. APSP Journal of Case Reports 4(3): 41.

5. Gupta RK (2010) Left lower quadrant acute abdominal pain: a case of spigelian hernia, a rare diagnosis by emergency ultrasound 20(4): 158-160.

6. Spangen L (1989) Spigelian hernia. World J Surg 13(5): 573-580.

7. Levy G, Nagar H, Blachar A, Ben Sira L, Kessler A (2003) Preoperative sonographic diagnosis of incarcerated neonatal Spigelian hernia containing the testis. Pediatr Radiol 33(6): 407-409.

8. Torzilli G, Carmana G, Lumachi V, Gnocchi P, Olivari N (1995) The usefulness of ultrasonography in the diagnosis of the Spigelian hernia. Int Surg 80(3): 280-282.

\section{Your next submission with Juniper Publishers will reach you the below assets}

- Quality Editorial service

- Swift Peer Review

- Reprints availability

- E-prints Service

- Manuscript Podcast for convenient understanding

- Global attainment for your research

- Manuscript accessibility in different formats

( Pdf, E-pub, Full Text, Audio)

- Unceasing customer service

Track the below URL for one-step submission https://juniperpublishers.com/online-submission.php 